\title{
A Study on Influencing Factors to Affect the Economic Status of Layer Poultry Farmers in Namakkal District of Tamilnadu
}

\section{Ravichandran $\mathrm{P}^{*}$ and Khan Mohamed A}

Department of Economics, Jamal Mohamed College (Autonomous), Tiruchirappalli - 620 020, India

\begin{abstract}
Poultry industry is one of the fastest growing segments of the agricultural sector in India. The important aspect of poultry development in India is the significant variation in the industry across different regions. Namakkal poultry farmers faced many constraints in poultry egg production due to climate factor, disease outbreak, poor quality of chicks, lack of quality feed and, Bio security, seasonal variations in egg prices and demand, poor infrastructural facility. The economic status of Namakkal poultry farmers highly influenced by the above said factors in day-today life. Among these factors, the climatic factor ranks first in affecting the economic status of poultry farmers. This factor influences the prices of the eggs, productivity of eggs. We conclude that if the poultry farm is not affected by climatic factor, the revenue would be more throughout the year. This study suggests that the poultry farmers may adopt a suitable precautionary method to prevent the outbreaks by climatic factor. Then the economic status of the poultry farmers will be in equilibrium.
\end{abstract}

Keywords: Poultry; Layer farm; Economic status; Solution factor; Constraints; Diseases; Egg price fluctuations

\section{Introduction}

An economy or economic system consists of the production, distribution or trade, and consumption of limited goods and services by different agents [1-4]. Economics is the social science that studies economic activity to gain an understanding of the processes that govern the production, distribution and consumption of goods and services in an economy [4]. Historically, India has classified and tracked its economy and GDP as three sectors - agriculture, industry and services. Agriculture includes crops, horticulture, milk and animal husbandry, aquaculture, fishing, sericulture, aviculture, forestry and related activities. Industry includes various manufacturing sub-sectors. India's definition of services sector includes its construction, retail, software, IT, communications, hospitality, infrastructure operations, education, health care, banking and insurance, and many other economic activities $[2,3]$

\section{Indian economy}

The economy of India is the tenth-largest in the world by nominal GDP and the third-largest by purchasing power parity (PPP) [5]. The country is one of the G-20 major economies, a member of BRICS and a developing economy that is among the top 20 global traders according to the WTO [6,7]. India was the 19th-largest merchandise and the sixth largest services exporter in the world in 2013; it imported a total of $\$ 616.7$ billion worth of merchandise and services in 2013 , as the 12th-largest merchandise and seventh largest services importer [8]. India's economic growth slowed to $4.7 \%$ for the $2013-14$ fiscal year, in contrast to higher economic growth rates in 2000s [9]. The Indian Finance Ministry projects the GDP growth for fiscal 2014 will be $5.5 \%$ [10]. IMF projects India's GDP to grow at $5.6 \%$ over 2014 15 [11]. Agriculture sector is the largest employer in India's economy but contributes a declining share of its GDP (13.7\% in 2012-13) [6]. Its manufacturing industry has held a constant share of its economic contribution, while the fastest-growing part of the economy has been its services sector - which includes construction, telecom, software and information technologies, infrastructure, tourism, education, health care, travel, trade, banking and other components of its economy.

The economy was then characterized by extensive regulation, protectionism, public ownership of large monopolies, pervasive corruption and slow growth $[12,13]$. Since 1991, continuing economic liberalization has moved the country towards a market-based economy $[12,13]$. By 2008, India had established itself as one of the world's faster-growing economies. Growth significantly slowed to $6.8 \%$ in $2008-09$, but subsequently recovered to $7.4 \%$ in $2009-10$, while the fiscal deficit rose from $5.9 \%$ to a high $6.5 \%$ during the same period [14]. India's current account deficit surged to $4.1 \%$ of GDP during Q2 FY11 against 3.2\% the previous quarter. The unemployment rate for 2012-13, according to Government of India's Labour Bureau, was $4.7 \%$ nationwide, by UPS method; and 3\% by NSSO method. India's consumer price inflation has ranged between 8.9 to $12 \%$ over the 2009 2013 periods [15].

\section{Poultry Industry in India}

- The Poultry Business in India is a very old practice and this food industry is one of the important contributors to the economy of rural and semi-urban India. India ranks seventeenth in the world poultry production index.

- Further, India is the fifth largest producer of eggs and ninth largest producer of poultry meat amongst all the countries.

- Indian Poultry Industry is 5,000 years old, since last 4 decades it began to witness remarkable growth from backyard to poultry industry.

- The organized sector of poultry industry is contributing nearly $70 \%$ of the total output and the rest $30 \%$ in the unorganized sector.

- The broiler industry is well dominated in southern states in our country with nearly $60-70 \%$ total output coming from these states.

- The layer industry once again is represented more in southern states especially, Andhra Pradesh, Tamil Nadu and Maharashtra producing nearly $70 \%$ of the country's egg production.

*Corresponding author: Ravichandran $\mathrm{P}$, Department of Economics, Jama Mohamed College (Autonomous), Tiruchirappalli - 620 020, India, Tel: 0431 2331135; E-mail: mba.ravichandran@gmail.com

Received January 30, 2015; Accepted April 07, 2015; Published April 17, 2015

Citation: Ravichandran P, Khan Mohamed A (2015) A Study on Influencing Factors to Affect the Economic Status of Layer Poultry Farmers in Namakkal District of Tamilnadu. Int J Econ Manag Sci 4: 242. doi:10.4172/2162-6359.1000242

Copyright: () 2015 Ravichandran P, et al. This is an open-access article distributed under the terms of the Creative Commons Attribution License, which permits unrestricted use, distribution, and reproduction in any medium, provided the original author and source are credited. 
- India's $75 \%$ of egg production consumed by the $25 \%$ population living in urban, semi-urban areas. Presently more than 800 hatcheries are operating in the country.

- India has emerged as the only country in the developing world a self-reliant, technology driven industry, with capability to produce every essential input for successful poultry farming including indigenous genetic resource and breeding, world class poultry vaccines and medicines, specific pathogen free eggs (SPF), farms and hatchery automation systems, pelleted feed, egg processing, poultry processing, nationwide network of disease diagnostic laboratories and facilities for entrepreneurial development and training in both private and public sectors [16].

\section{Benefits of poultry farming}

The poultry farming is very versatile agro-business and it provides some benefits. They are

- It was source of high quality human food. Egg is not only supports in nutritive value, nut also it is very easily digested and cab be served indifferent ways. Of this also used in many ways like binders and levering agents in banking and furnishes richness in ice-cream, sauces, curlards and candues

- Poultry farming is highly adaptable under various conditions. It fits well in mixed farming system to provide continuous income to the farmers during their lean periods and also helps to engage their family labor profitable throughout the year.

- It provides employment avenues. There are many diversified types of business allied poultry farming like egg production, broiler production. All these business can develop as rural industries, which will have many avenues of employment of rural side particularly among educated unemployed and under-employed persons.

- Poultry waste is an excellent source of organic manure, which can utilized for growing field crops. It estimated that of the poultry manure utilized properly, it could produce more food grains them the birds consume as feed.

- It serves as source of raw materials for industrial products. Eggs have many industrial uses in preparation of vaccines, varnished printers land, soap, shampoo etc. Eggshells are using as minerals in animal feed. Endocrine glands of birds are using for preparation of hormones and any other biological preparations.

\section{Profile of the Study Area (Namakkal District, Tamilnadu, India)}

Namakkal District is an administrative district in the state of Tamil Nadu, India. The district was bifurcated from Salem District with Namakkal town as Headquarters on 25-07-1996 and started to function independently from 01-01-1997. The district has 4 taluks (subdivisions); Tiruchengode, Namakkal, Rasipuram, Velur and Kolli Hills (in descending order of population) and has two Revenue Divisions; Namakkal and Tiruchengode. It was ranked second in a comprehensive Economic Environment index ranking of districts in Tamil Nadu not including Chennai prepared by Institute for Financial Management and Research in August 2009. It was major source of Tamil Nadu Economy. As of 2011, Namakkal district had a population of $1,726,601$ with a sex-ratio of 986 females for every 1,000 males.

\section{History}

After the struggle between the Cheras, Cholas and Pandyas, the Hoysalas rose to power and had the control till the 14th century followed by Vijayanagara Empire till 1565 AD. Then the Madurai Nayakas came to power in 1623 AD. Two of the Poligans of Tirumalai Nayak namely, Ramachandra Nayaka and Gatti Mudaliars ruled the Salem area. The Namakkal fort is reported to have been built by Ramchandra Nayaka. After about 1635 AD, the area came successively under the rule of Muslim Sultans of Bijapur and Golkonda, Mysore kings and then the Marattas, when about the year 1750 AD Hyder Ali came to power. During this period, it was a history of power struggle between Hyder Ali and later Tippu Sultan, with the British.

\section{Geography}

Namakkal district is bounded by Salem district on the north; on the east by Attur taluk of Salem district, Perambalur and Tiruchirapalli District's; by Karur District on the south and on the west by Erode district.

Namakkal District comes under the North Western Agro climatic zone of Tamil Nadu. It is situated in the dividing portion of two watersheds between Cauvery and the Vellar System with the Taluks of Attur, Rasipuram and Namakkal on the East and Salem, Omalur and Mettur on the West. Tiruchengode taluk alone is placed under Western Agro-climatic zone.

Besides the above two zones, Kolli and a few isolated hills and ridges are scattered over Namakkal, Rasipuram and Tiruchengode and along with the valleys and rolling hills, make up the characteristic topography of the district.

\section{Demographics}

According to 2011 census, Namakkal district had a population of $1,726,601$ with a sex-ratio of 986 females for every 1,000 males, much above the national average of 929 . A total of 150,699 were under the age of six, constituting 78,754 males and 71,945 females. Scheduled Castes and Scheduled Tribes accounted for $20 . \%$ and 3.3\% of the population respectively. The average literacy of the district was $68.12 \%$, compared to the national average of $72.99 \%$. The district had a total of 475,511 households. There were a total of 898,245 workers, comprising 152,497 cultivators, 228,614 main agricultural labourers, 35,156 in house hold industries, 422,885 other workers, 59,093 marginal workers, 5,976 marginal cultivators, 25,112 marginal agricultural labourers, 3,641 marginal workers in household industries and 24,364 other marginal workers.

\section{Industry}

The main occupation in the district is agriculture. The cultivation generally depends on monsoon rains, wells and tanks. Nearly 90 percent of the cultivated area is under food crops. The principal cereal crops of this district are paddy, cholam, cumbu and ragi. Panivaragu, Kuthiraivali, Samai Varagu and Thinai are some of the millets cultivated. Among pulses, the major crops are redgram, blackgram, greengram and horsegram. Among oil seeds groundnut, castor and gingelly (sesame) occupy important places. Of the commercial crops, sugarcane, cotton and tapioca are some of the important crops. Tapioca is used for the manufacture of sago.

Namakkal district is noted for Truck and Lorry external body building which dates back to 1956. Throughout India Tiruchengode is known for its Body Building industry for Trucks, Trailers, Tankers and Rig Unit. Finished trucks and Rig Units are even exported to foreign countries from Namakkal. Nearly 25000 people are employed either 
directly and indirectly in truck body building activity and about 300 units in Namakkal and 100 Units in Tiruchengode are engaged in this activity.

Poultry development has been rather phenomenal in the district of Namakkal. The district is also well known for its poultry and dairy industries, accounting for a bulk of supply of poultry products to neighbouring industries. In fact, Namakkal produces about $65 \%$ of the egg output of Tamil Nadu.

\section{Factors Affecting the Egg Production}

There are many factors that can adversely affect egg production. Unraveling the cause of a sudden drop in egg production requires a thorough investigation into the history of the flock. Egg production can be affected by such factors as feed consumption (quality and quantity),water intake, intensity and duration of light received, parasite infestation, disease, and numerous management and environmental factors [17].

Following sharp declining in prices, egg farmers in Namakkal, which accounts for 20 per cent of country's production, is now seeing some price correction. Poultry farms in the Namakkal cluster in Southern Tamil Nadu produce around 3.08 crore eggs a day. About 40 per cent of the total eggs are consumed by the Kerala market and by schools in Tamil Nadu under the free meal programme. Around 45 lakh eggs are supplied a day for the Mid-day Meals scheme, according to sources. The other major market was Hyderabad. Every day around 30 lakh eggs are exported from Namakkal.

The increase of demand in Hyderabad now has an impact in the price of eggs in Namakkal. If the demand is high in Hyderabad, the eggs from Namakkal could be transported there, which helps the distributors. The ban on fishing in the west cost of the country, such as in Kerala, has increased demand of eggs there and generally, during the rainy season the demands are high, which is the reason for the increase in prices. Given the current trend, the prices are expected to go up further in the coming days, which would help the poultry farmers who has been suffering in the past. Consumption is also good in Mumbai and Gujarat and this is reflecting in the increase of prices in the national level.

Orders from all the three major consumers-Andhra Pradesh, Kerala and Tamil Nadu -- dropped drastically, which in turn brought down the rates drastically earlier, says the Egg Producers Association representatives. Order from the Tamil Nadu Government was reduced due to the Election Code of Conduct on supplies for mid day meals.

\section{Research Methodology}

This study is an empirical study based on survey method. The data collected for the study both primary and secondary data collected from journals and magazines. Primary data were collected directly from the farmers through personnel interview method aided by a schedule. Secondary data has collected from various books, journals, magazines, periodicals, reports, websites, official documents and unpublished thesis and veterinary doctors.

\section{(a) Field work}

The field work was carried out during the year 2012 to 2014. Each interview took about half a day. Nearly 350 poultry farm entrepreneurs were interviewed for collecting data. The interview was conversational in style and respondents were made to feel at home and easy.

\section{(b) Limitations}

Estimation of the economic status for the previous years was difficult. Most of the poultry farmers do not keep correct accounts of their receipts and expenditures or any other statistical data. Most of them are given by the respondents only from their memory which may not be accurate. However, every effort has been taken by researcher to collect the data as accurate as possible.

\section{Data collection}

After identifying and defining the research problem and determining specific information required to solve problem, the researchers task is to look for the type and sources of data, which may yield the defined results. Generally, the researcher straight away resorts to survey method for data collection.

\section{Primary data}

Primary data may pertain to socio-economic characteristics of the entrepreneur attitudes and opinions, their awareness, knowledge and other related aspects, like education, monthly expenditure etc.

\section{Data collection method}

The primary data has collected with the help of structured interview schedule and it has supplied to the selected respondents. Secondary data has collected from various books, journals, magazines, periodicals, reports, websites, official documents and unpublished thesis.

\section{Analysis of the Study}

Data on National Egg Coordination Committee (NECC) Namakkal, egg price for the three years from 2012-2014 was collected from the secondary sources and analyzed for understanding the trends of egg prices during this period. Centralized Moving Average Method was employed in this Time Series data and forecasting of egg price for 2014 was carried after putting factors for cyclical and seasonal trends. Considering the egg prices during this period, mean annual price index for the three years were Rs.292.02, 339.57 and 315.41. Highest egg price was reported predominantly in the month of November and lowest in April (Table 1).

As per season wise analysis, lowest egg price was reported in summer and highest in Post monsoon period. The mean difference between highest and lowest egg price in the year 2014 was 36.2, indicates the high fluctuations in the egg prices during the reported period. Based on the Table 2, the highest egg price was forecasted in November -2014 (Rs.353.83) and lowest in April -2014(Rs.258.13) with the mean annual egg price of Rs.315.41

The above Table 2 shows the average egg price for month wise in the study period. These average prices have applied to a graph (Figure 1).

The above graph shows the average egg price in the study period. The information from the above graph the summer period the poultry farmer's economic ratio has got down in each year. This economic fluctuation has created by the climate.

\begin{tabular}{|l|l|c|c|c|}
\hline Season & Duration & $\mathbf{2 0 1 4}$ & $\mathbf{2 0 1 3}$ & $\mathbf{2 0 1 2}$ \\
\hline Winter & December-March & 335 & 329.6 & 269.2 \\
\hline Summer (Pre-monsoon) & April-June & 298.8 & 318.3 & 270.2 \\
\hline Rainy (Monsoon) & July-September & 307.1 & 330.1 & 319 \\
\hline Autumn (Post-monsoon) & October-November & 330.3 & 367.8 & 312.3 \\
\hline
\end{tabular}

Table 1: Season wise average egg price in the study period. 
Citation: Ravichandran P, Khan Mohamed A (2015) A Study on Influencing Factors to Affect the Economic Status of Layer Poultry Farmers in Namakkal District of Tamilnadu. Int J Econ Manag Sci 4: 242. doi:10.4172/2162-6359.1000242

\begin{tabular}{|c|c|c|c|}
\hline \multirow{2}{*}{ Month } & \multicolumn{3}{|c|}{ Year } \\
\cline { 2 - 4 } & $\mathbf{2 0 1 4}$ & $\mathbf{2 0 1 3}$ & $\mathbf{2 0 1 2}$ \\
\hline January & 343.87 & 336.9 & 284.58 \\
\hline February & 319.82 & 365.86 & 261.66 \\
\hline March & 294.94 & 310.16 & 261.39 \\
\hline April & 258.13 & 296.67 & 230.33 \\
\hline May & 314.52 & 289.45 & 269.45 \\
\hline June & 323.83 & 368.9 & 310.83 \\
\hline July & 316 & 334.68 & 290.03 \\
\hline August & 282.26 & 323.55 & 311.03 \\
\hline September & 323 & 332 & 356.07 \\
\hline October & 306.68 & 345.84 & 314.52 \\
\hline November & 353.83 & 389.77 & 309.17 \\
\hline December & 348.1 & 381.16 & 305.29 \\
\hline Average & $\mathbf{3 1 5 . 4 1}$ & $\mathbf{3 3 9 . 5 7}$ & $\mathbf{2 9 2 . 0 2}$ \\
\hline
\end{tabular}

Table 2: Month wise Average Egg price during the Study Period.

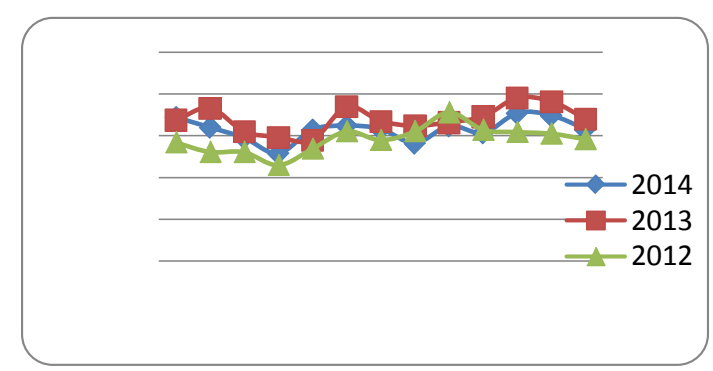

Figure 1: Graph for Month wise Average Egg price during the Study Period.

The above Table 3 shows the Average Maximum temperature has recorded in Namakkal District, Tamilnadu, India. Due to climate factor the birds had been suffered by combined diseases. So, the people do not prefer to take these kind of foods in the summer period (Figure 2).

The above graph shows the average maximum temprature recorded in study area. In this study conclude that the summer period the birds were being affected by the combined diseases. Due to incrase the economic status of the poultry farmers we have to give the precautionary measures which have to follow the poultry farmers in the summer period. If the poultry farmers save the birds from disease outbreak during the summer period, definitely they will get unflectuated economic status.

The above Table 4 shows the birds affected by Diseases in the particular time duration in the study area and the poultry farmers getting the outbreaks which was created by the diseases. The above table shows the poultry farmers had achieved the production to this extend in the study area in the year 2014 .

\section{Various Diseases Occurance in Poultry}

Prevalence of various diseases in layers is discussing in this section under various subsections as follows:

\section{Mareks disease}

Mareks is one of the important diseases of chicken characterized by leg paralysis and lymphocyte infilteration of brachial and sciatic nerves, potentially causing $4.2-20.8 \%$ mortality in layers.

\section{Infectious bursal disease}

Infectious Bursal Disease (IBD) also known as Gumboro had been reported to cause heavier losses in chickens (75 - 85\%). The disease is characterized by lameness, severe morbidity and mortality in chicken. It is considered as AIDS of the chicken, because it adversely affects the chicken's immune system.

\section{Newcastle disease}

Newcastle disease is one of the destructive diseases of chickens characterized by severe mortality, greenish diarrhea and thirst. The birds tend to drink more water and decrease their consumption of feed. Newcastle disease caused 60\% losses in egg type layers (Savic, 1999); however, lower losses of $12.58 \%$ had also been reported by Srithar et al. On any standard these losses were high because the increase in mortality beyond $8-10 \%$ was not admissible in egg type layers. Aside from higher mortality, Newcastle disease caused a 15\% drop in eggs of infected flocks and simultaneously resulted in $5 \%$ soft shell eggs.

\section{Infectious coryza}

Infectious coryza is also an important bacterial disease of chickens characterized by respiratory complications, swollen head syndrome, nasal discharge and severe drop in egg production. The most common cause is Haemophilus gallinarum. Conditions of poor hygiene, chilly environment and adverse climate exposure could work as predisposing factors for the onset of this disease. Chickens of all type and age were found susceptible to this infection and the disease caused 2-5\% mortality and 35\% drop in egg production.

\begin{tabular}{|c|c|}
\hline Month(2014) & $\begin{array}{c}\text { Average Maximum } \\
\text { Temparature }\end{array}$ \\
\hline January & 30.645 \\
\hline February & 33.285 \\
\hline March & 36.193 \\
\hline April & 39.767 \\
\hline May & 37.806 \\
\hline June & 38.833 \\
\hline July & 37.677 \\
\hline August & 36.774 \\
\hline September & 37.067 \\
\hline October & 33.548 \\
\hline November & 30.067 \\
\hline December & 30.162 \\
\hline
\end{tabular}

Table 3: Average Maximum temperature has recorded in the Study area in the year 2014.

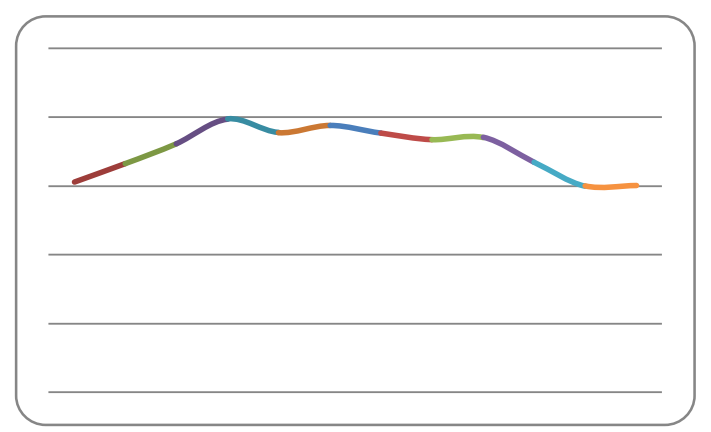

Figure 2: Graph for average maximum temperature in the study area during the year 2014 . 


\begin{tabular}{|c|c|c|c|}
\hline Month & Diseases & $\begin{array}{c}\text { Disease } \\
\text { Outbreaks }\end{array}$ & $\begin{array}{c}\text { Average } \\
\text { Production }\end{array}$ \\
\hline January & Ranikhat & $3 / 100$ & $85 \%$ \\
\hline February & Ranikhat & $2 / 100$ & $87 \%$ \\
\hline March & Ranikhat,ILD & $6 / 100$ & $81 \%$ \\
\hline April & Ranikhat,ILD & $5 / 100$ & $82 \%$ \\
\hline May & $\begin{array}{c}\text { VVND, ILD, } \\
\text { Ranikhat, } \\
\text { (combined } \\
\text { diseases) }\end{array}$ & $9 / 100$ & $80 \%$ \\
\hline June & Ranikhat & $3 / 100$ & $85 \%$ \\
\hline July & Ranikhat,ILD & $4 / 100$ & $84 \%$ \\
\hline August & Ranikhat,ILD & $2 / 100$ & $87 \%$ \\
\hline September & Ranikhat,ILD & $2 / 100$ & $87 \%$ \\
\hline October & Ranikhat,ILD & $2 / 100$ & $87 \%$ \\
\hline November & Ranikhat,ILD & $3 / 100$ & $85 \%$ \\
\hline December & Ranikhat,ILD & $2 / 100$ & $87 \%$ \\
\hline
\end{tabular}

Table 4: The birds affected by Diseases in the particular time duration in the study area.

\section{Infectious bronchitis}

Highly infectious viral disease characterized by respiratory symptoms, increased mortality and decreased egg production. The disease could occur at any stage of the chicken's life and during any season of the year. However, it was found to be more prevalent $(35.7 \%)$ in 7 days to 5 weeks of age with special reference to its higher incidence $(66.6 \%)$ in the winter season.

\section{Avian influenza}

Avian influenza is an important poultry disease that had emerged with higher mortality in the recent decades. This disease caused $90 \%$ morbidity and $80 \%$ mortality in 30 week aged chickens. Pathogenisity of avian influenza was more in egg laying birds than in broilers.

\section{Mycoplasmosis}

Mycoplasmosis is a series of bacterial infections caused by bacterium mycoplasm of various types in egg type layers. Mycoplasmosis results in severe economic losses in egg type layers in terms of reduced egg production and higher mortality.

\section{Salmonellosis}

Salmonellae, one of the bacterial species, are abundantly found in most of the areas where chances of contamination are greater; primarily poultry sheds and feed reservoirs. Salmonella had also been isolated from litter (42\%), drinking water (36\%), feed (28\%) and water tanks $(17 \%)$ in poultry premises.

\section{Coccidiosis}

Coccidiosis a protozoan disease, is one of the major problems of the chicken industry, characterized by blood tinged feces, ruffled feathers, loss of appetite, poor growth and reduced egg production. Coocidiosis had been reported to result in higher mortality (51.38\%) and economic losses ( $\$ 35$ to $\$ 200$ million/year in USA; Hofstad et al.).

\section{Yolk Sac Infection}

It is one of the most common bacterial infections of chicken observed during the first few weeks of a chicken's life. Drowsiness, minimal mobility, vent pasting and the lack of interest of feeding in the chicken characterize yolk sac infection. There may be several predisposing factors such as poor hygiene and stressful conditions leading to this anomaly because, it is a general bacterial infection.

\section{Escherichia coli}

E. coli is one of the major problems in chicken production influencing heavier losses and severe drop in egg production. About $5.5 \%$ mortality and $10-20 \%$ drop in eggs was observed with E. coli infections in egg type layers reared in cages. Zanella et al. also reported 5-10\% mortality due to $E$. coli infections with no pronounced signs, suggesting that the infection may be there but couldn't be easily detected until regular tests are performed for its proper diagnosis.

\section{Egg prolapes and cannibalism}

Egg prolapes has become one of the major issues in egg type layers during the past few years. Egg prolapes could cause higher mortality and in turn, would result in huge economic losses. The authors reported 9.4\% egg prolapse cases in egg type layers. Abrahamsson and Tauson reported cannibalism as the picking habit of chicken, causing $4-20 \%$ mortality.

\section{Aflatoxicosis}

Presently, aflatoxicosis is one of the major issues in chicken production. The common cause of aflatoxicosis is contaminated feed, resulting in higher mortality and severe drop in egg production. Prathapkumar et al. reported 10\% mortality and 20\% drop in egg production due to aflatoxin B1 in the diet. Drop in egg production was as higher as $26-55 \%$ with increased level of aflatoxin B. To avoid such losses it is important to regularly monitor feed quality. In case of aflatoxicosis, change of feed will be a better option. Choudary also reported reduction in mortality and gradual increase in egg production when feed suspected for aflatoxicosis was changed.

\section{Interstitial lung disease}

Interstitial lung disease is a general category that includes many different lung conditions. All interstitial lung diseases affect the interstitium, a part of the lungs' anatomic structure. The interstitium is a lace-like network of tissue that extends throughout both lungs. The interstitium provides support to the lungs' microscopic air sacs (alveoli). Tiny blood vessels travel through the interstitium, allowing gas exchange between blood and the air in the lungs. Normally, the interstitium is so thin it can't be seen on chest X-rays or CT scans.

\section{Types of interstitial lung disease}

All forms of interstitial lung disease cause thickening of the interstitium. The thickening can be due to inflammation, scarring, or extra fluid (edema). Some forms of interstitial lung disease are shortlived; others are chronic and irreversible.

Some of the types of interstitial lung disease include:

Interstitial pneumonia: Bacteria, viruses, or fungi may infect the interstitium of the lung. A bacterium called Mycoplasma pneumonia is the most common cause.

Idiopathic pulmonary fibrosis: A chronic, progressive form of fibrosis (scarring) of the interstitium. Its cause is unknown.

Nonspecific interstitial pneumonitis: Interstitial lung disease that's often present with autoimmune conditions (such as rheumatoid arthritis or scleroderma).

Hypersensitivity pneumonitis: Interstitial lung disease caused by ongoing inhalation of dust, mold, or other irritants.

Cryptogenic organizing pneumonia (COP): A pneumonia-like 
interstitial lung disease but without an infection present. COP is also called bronchiolitis obliterans with organizing pneumonia (BOOP).

Acute interstitial pneumonitis: A sudden, severe interstitial lung disease, often requiring life support.

Desquamative interstitial pneumonitis: An interstitial lung disease that's partially caused by smoking.

Sarcoidosis: A condition causing interstitial lung disease along with swollen lymph nodes, and sometimes heart, skin, nerve, or eye involvement.

Asbestosis: Interstitial lung disease caused by asbestos exposure.

\section{Causes of interstitial lung disease}

Bacteria, viruses, and fungi are known to cause interstitial pneumonias. Regular exposures to inhaled irritants at work or during hobbies can also cause some interstitial lung disease.

\section{Ranikhet disease}

Ranikhet disease, also known in the West as Newcastle disease is a contagious and highly fatal daises of flows. In spite of the notable work done towards its control, this disease still ranks as one of the most serious virus diseases of poultry. The disease occurs in almost all countries and usually assumes a server form affecting birds of all ages. Mortality in flows varies from 50 to 100 per cent.

Ranikhet disease is largely a disease of flows, but it also effects turkeys, pigenosn, grows, ducks, geese, koel pheasants, guinea-flows, partridges and doves. hedgehogs have been suspected as reservoirs of the disease. The disease is also suspected to cause conjunctivitis among laboratory workers and persons handling infected birds.

\section{Necrotic enteritis}

Necrotic enteritis (NE) is an acute Clostridium infection characterized by severe necroses of intestinal mucosa. The disease begins suddenly, with a sharp increase in death rate. A strong dehydration is observed. The skin is sticked on or adhered to body musculature and is hardly removed.

\section{Treatment and Prevention}

At present there is no effective treatment of any value. Proper housing and general good care are indicated in an effort to shorten the duration and severity of the infection.

An early recognition of the disease and application of struck sanitary measures are of great value in the control of the disease. Some important measures for its prevention are ; slaughtering of all apparently ailing birds, segregating of in - contact in group of 10 to 15 each; removal of all infective materials such as droppings, residues of poultry cleanliness; and provision of separate attendants for each group of birds.

The poultry farm should be at a distance from place of traffic. All newly purchased birds should be kept in segregation from not less than 10 days before taking them into the farm. The poultry runs should be ploughed from time to time and lime applied thereon as a general disinfectant. As far as possible the pens and runs should be made inaccessible to free-flying birds by providing a barrier of wire - netting.

\section{Control}

Control of Ranikhet diseases can be effect with judicious application

\begin{tabular}{|c|c|c|c|}
\hline Age & Disease & Vaccine & Route \\
\hline 1 day & Marek's & HVT vaccine & I/M \\
\hline $5-7$ days & RD & Lasota/F & Occulonasal \\
\hline $10-14$ days & IBD & IBD Live & Drinking water \\
\hline $24-28$ days & IBD & IBD Live & Drinking water \\
\hline 8th week & RD & R2B/RDVK & S/C \\
\hline $16-18$ week & RD & Killed/Live & S/C \\
\hline
\end{tabular}

Table 5: Vaccination Programme for Layer Type Chicken. Source: www.vuatkerala org

of sanitary and vaccination measures. The possibility of entry and spread of infection is considerably reduced through the maintenance of flock on deep little system and stopping all unauthorized entries, even of human beings, into the battery brooders. Disposal of fowl carcasses by burning or deep brutal to reduce the scope of carrion-eating birds like crows, kites and vultures perching near fowl pens or poultry farms helps to resume the hazards of this infection. Two types of vaccines are available in India, one for the adult birds an another for younger birds or body chicks. The virus strain for Ranikeht disease vaccine used for adult birds age over weeks was evolved at the Indian veterinary Research Institute. The vaccine consists of freeze - dried virus grown in chick embryos. Vaccination of birds 6 weeks old and above confers immunity for 1 to 3 years. Care should be taken to vaccinate bird's not carrying heavy coccidian infection. Birds with heavy worm infection or coccidiosis are not protected even with a good vaccine. There are sometimes complications side reactions following vaccination. There are sometimes complications side reactions following vaccination with 'Mukteswar' strain of Ranikhet disease vaccine. These consist on incoordination of limbs and sometimes paralysis in 1 to 3 per cent to the vaccinated birds. The reactions may become more acute if the birds are affected with roundworms, coccidiosis or are weak on account of malnutrition. Thus, it is advisable to store feed ingredients or ration in proper places to avoid its contamination by microorganisms. In addition, preference shall be given to fresh feed rather than stale or feed stored for longer durations. Inappropriate and prolonged storage conditions would encourage microorganism to contaminate feed rendering them unsafe for sue and better performance (Table 5).

\section{Conclusion}

From the above study, we concluded that the poultry farmers had severe economic fluctuations due to climatic factor along with other constraints. If the poultry farmers adopt suggested measures in production, they may get relief from the economic fluctuations. This paper has further scope for doing research on preventive disease management, production management in order to avoid economic fluctuations of poultry farmers.

\section{References}

1. Narasimhan TE, Gireesh Babu (2012) Prices of egg from Namakkal increases after a lull.

2. Indian Economy Government of India (2013)

3. Employment across various sectors, NSSO 66th Nationwide Survey, Planning Commission, Government of India.

4. en.wikipedia.org/wiki/Economics

5. "India". International Monetary Fund.

6. Agriculture's share in GDP declines to $13.7 \%$ in $2012-13$ The Economic Times.

7. World Trade Organization, World Trade Report 2013, Geneva, ISBN 978-92870-3859-3.

8. Modest trade growth anticipated for 2014 and 2015 following two year slump World Trade Organization, 
Citation: Ravichandran P, Khan Mohamed A (2015) A Study on Influencing Factors to Affect the Economic Status of Layer Poultry Farmers in Namakkal District of Tamilnadu. Int J Econ Manag Sci 4: 242. doi:10.4172/2162-6359.1000242

9. RBI governor Raghuram Rajan meets Narendra Modi LiveMint.

10. Mid-Year Economic Analysis 2014-2015, The Indian Finance Ministry.

11. IMF projects India's GDP to pick up in 2015 to 6.4 per cent". The Economic Times.

12. Economic survey of India 2007: Policy Brief" OECD.

13. Goldman Sachs (2007) India's Rising Growth Potential.
14. Economic Survey 2010, pp. 1-2.

15. Inflation, consumer prices (annual \%) The World Bank (2014)

16. http://www.gktoday.in/indian-economy-meat-poultry-industry-of-india-nationalmeat-and-poultry-processing-board/

17. Jacob JP, Wilson HR, Miles RD, Butcher GD, Mather FB (1998) Factors Affecting Egg Production in Backyard Chicken Flocks 5-35 